\title{
Research on the Development and Risk Regulation of Internet Finance
}

\author{
Wenjie Huang ${ }^{1,}$, Shujun $\mathrm{Ye}^{2, \mathrm{~b}}$ \\ ${ }^{1}$ School of Economics and Management, Beijing Jiaotong University,Beijing,China \\ ${ }^{2}$ School of Economics and Management, Beijing Jiaotong University,Beijing,China \\ a14120482@bjtu.edu.cn, bshjye@bjtu.edu.cn
}

Keywords: Internet financing, Balance of Treasure; P2P, Third-party Payment; Risk Regulation Abstract. The representative products of Internet Finance such as the balance of treasure, P2P, third-party payment have some impacts and influences on traditional bank businesses, with both risks and opportunities. On one hand, it is a new stage of innovation development of finance industry in the Internet Age; on the other hand, the situation of "three without" that access without any limits, industry without any rules, regulations without any institutions-also hides huge credit risks. Aimed at the risks existing in the financial products, credit platforms and third-party payments, some specific strategies on Internet Financing are put forward

\section{Introduction}

Since Alibaba launched the balance of treasure in 2013, the domestic Internet finance has been appearing explosive growth. All new kinds of Internet financial products have made a notable influence on the traditional business, such as banking, securities, fund, insurance, etc. Internet finance is quickly expanding its scale and crowding out the three core business of the market that is deposits, loans and payment. To a certain extent it also promotes the marketization of interest rate and speeds up the step of financial innovation in our country. Due to a large number of clients turning financial resources to the Internet to obtain a higher return on investment, the risk of this phenomenon also became the focus of social. Since the deal sum of balance of treasure estimated at nearly $¥ 400$ billion, to bring the Internet financial into the financial regulatory system is very necessary. Guidance of No. 221 article issued by Ten ministries and commissions in December of 2015, which is a comprehensive summary, combing and acknowledgement of the Internet financial forms for recent years, as well as the landing "guideline" framework file for future regulatory policy. Therefore, we need to research and discuss about the development situation of Internet finance, and further for the specific mode and risk regulation strategy of Internet finance.

\section{The Main Mode and Risk of Internet Finance In China}

Internet finance is a new combination of the internet technology and information communication, combined by traditional financial institutions or enterprises. This new model of business includes financing, payment, investment, and information intermediary services. The main forms include online banking, online securities, insurance, network goods online, online payment, online settlement, etc. Chinese Internet financial service is mainly divided into payable settlement, financing, investment insurance, etc. Analyzes its potential risks based on the characteristics of each part.

1.1 P2P Network Loan Platform and Its Risk. P2P network loan platform is a financing mode of individual to individual, which use the third-party Internet platform to connect suppliers and demanders of funds servicing for individuals and small businesses. Since 2014, Chinese internet finance industries represented by P2P have break out much crisis. Such as the absconding borrowers, missing money, as well as the platforms stagnated by unable to pay. The most advanced 
representative is Ezubao. It has allegedly absorbed about 74.7 billion Yuan in funds, with about 890,000 investors involved. This miracle platform of the Internet financial left these investors only traumas cannot subside. Even dare not to believe Zhang min , the president of parent company of Anhui Niucheng holding group, once said with beauty and a smile-" Obtain wealth between hands" in the CCTV prime-time. All the saving and even endowment money of some investors has completely vanish. In our country, the P2P loan network platform has four main patterns. The first is an only platform pattern, such as "PPdai". This pattern is similar to the business of direct financing. The network platform does not provide guarantees, but provide the intermediary services between creditors and borrowers to ensure co-ordination of financial supply and demand. The second is the pattern of principle-guarantee, such as the "Red ridge Ventures". It is a P2P platform that provides lenders with the assurance of the principal or the interest rate. But most of the platform is neither specify the source of cash deposit nor the risk petty cash, as well as the usage and dynamic scale of risk petty cash. There is no specification of the subject to liability, and whether the platform provide security only within the limit of the risk reserve fund .The third pattern is the securitization of credit assets, such as "Lufax" and " Beneficial Net". Securitization of credit assets refers to turn the fixed financial asset into negotiable securities of capital market. Some guarantee agencies and small loan companies carry out cooperation by establishing its own P2P platform or the third-party P2P platform. They sold the guaranteed products or small credit assets to investors through the P2P platform, the process is similar to the securitization of credit assets. The fourth is the creditor's rights transfer modes, such as "Yixin". In this pattern, both sides of the contract is signed not directly, but lend capital to demanders by a third party, then money lenders to transfer creditor's rights to the other investors. There are three common risks of P2P loan network platform. As follows, the first one is the loan will not be pay. If the borrower is fraud, breaches of contract or fails, lenders will not repaying the principal or the earnings, this is the main risk to the lenders; The second is net-credit platform collapse. Net platform could shut down due to losses. Therefore no one is responsible for the loans that not yet repay; The third is the information security risk.

1.2 Other Monetary Fund Combined with Alipay and Their Risks. With the rapid development of this Internet economy society, many financial products are emerging in endlessly. Among them, in June 2013, Alibaba's alipay launched a new financial product named "balance of treasure". It allows users to balance in the account of value-added. Not only users can put the money stored in the alipay for shopping, but also can be directly used in purchasing money funds and other financial products on this platform. Balance of treasure was established in June 2013, 180 billion Yuan have been set six months later. On March 19, 2014, we had data to show that its size has more than 547.7 billion Yuan. Celestica fund is responsible for the management and operating of this fund products. Its operation mode is to binding the account of alipay into a vast pool of funds, then deposit into the interbank market that custom cannot investment. Celestica's investment strategy is to deposit most of the capital in banks with agreement repay, and the term of this agreement is mainly 6 months. A small amount of money for treasury bonds repurchases.

Internet monetary fund represented by the alipay is mainly faced with several types of risks: liquidity risk. Investment assets of balance of treasure heavily rely on inter-bank deposits and the risk of high asset concentration ratio is obviously existed. Moreover, earnings of balance of treasure for investors is counted on a daily basis but the period of bank monetary fund invested is relatively long, bringing great structural risks and mobility bank run risk for assets and liabilities deadline. Mobility guarantees of balance of treasure mainly come from two aspects: on the one hand, preferential policy of bank monetary fund draws the bank agreement deposit in advance. Actually, 
competition about capital snatch is existed between balance of treasure and banks, making the interbank negotiable certificates of deposit be faced with fluctuation risks. On the other hand, financial products just like balance of treasure also make profits through the interest arbitrage of control of interest rate, and balance of treasure would immediately be up against earnings upside down and liquidity risks once the preferential policy is cancelled by China Banking Regulatory Commission and interest rate would be completely marketed. Meanwhile, phenomenon of fund redemption much larger than subscription would appear if price of market fund declines and the fund is withdrew quickly by investors, and the fund company must draw the bank agreement deposit in advance. If interests of the fund company is stilled calculated by the bank according to the fixed rate of agreement deposit, liquidity risk would be avoided by monetary fund but it actually has been transferred to traditional financing institution, which is easily lead to drastic fluctuation for the monetary market and even affect stabilization of the whole financial market.

1.3 Third-Party Payment and Risk. The third-party payment means nonbanking concerns offer retail payment service, mainly include provide intermediary services of collection expenses and payment through internet payment function, merchant acquiring service of prepaid and bank cards. 270 enterprises have been acquired the third party payment license up to June, 2016. According to the People's Bank of China on aspect of third party payment, in 2015, accumulative 82.145 billion times of internet payment service happened for non-bank payment institution, the amount was RMB 49.48 trillion with year-on-year growth of $119.51 \%$ and $100.16 \%$. The third party payment is mainly divided into two modes of platform account and payment gateway. The essence of the first mode with the payment company as credit intermediary is that temporarily holds the payment for goods instead of buyers and sellers, before goods acknowledge receipt of the buyer, such as the alipay and tenpay. The second mode is just a simple channel to link the bank and buyer together, the seller would be paid by the buyer though the third party payment platform to realize payment on line. It is inconvenient and the actual application value it provides is limited. The representative products are IPS, quick money and Karaka etc. At present, risks of third party payment market mainly are two types: on one hand, all the inherent risks of third party payment industry, for example, fund precipitation, information security, financial crimes conducted by utilizing the third party payment channel and other risks; on the other hand, risks related to the development characteristic of the existing third party payment market, including single fault risk produced by corner on the market, namely the financial risks that the whole payment market won't be orderly operated if problems appear with some payment provider and permeate to capital allocation etc. fields due to payment transaction. In 2015, the third-party internet payment transaction scale reached RMB 11.8 trillion, of which alipay and tenpay respectively accounted for $47.6 \%$ and $20 \%$ of market shares. Systematic financial risk might be triggered even economic stabilization might be impacted if problems appear for alipay or tenpay and involves clearing internet financial payment service.

1.4 Crowd Funding Mode and the Risks. Crowd funding business model means idea man or small and micro businesses etc. project sponsors (fundraisers) create the page on website of crowd funding after examined and approved by intermediary agent (crowd funding) to introduce project status to the public (contributor) and to collect small cap holdings for the public or seek other material supports. Crowd funding mode, actions about pre-order or pre-sell, is evolved from advances on sales, and the advances on sales might be transformed to internet creative anticipated products and service investments from anticipation network orders and advances on sales through the internet. Up to the end of 2014, 1250 global crowd funding platforms have been formed. In July of 2011, the on-line "Roll Time” was the first domestic crowd funding with the largest scale; up to 
July of 2013, more than 7000 project proposals have been received for the platform, including about 700 on line projects and the successful ratio was approximate 50\%.

According to return contents of investor, the crowd funding can be divided into four types: First, commodity crowd funding platform, namely the return of investment refers to products or services investors acquired. Second, stock right crowd funding platform, investors gain some stock rights of crowd funding to acquire returns by conducting according to the corresponding market rules. Third, creditor's rights crowd funding platform, namely investors acquire partial creditor's rights of enterprise to gain interests and take the capital back in the future (which is obviously different form equity crowd funding), requiring investors learn more about it to lower the risks. Four, public benefit crowd funding platform, namely supporters finance to donate and help others without requiring a return or just accepting small symbolic articles. General speaking, fund-raising target would be set for each item by the crowd funding platform, and money will be sent to investors' account if failing to reach the target. There are mainly three aspects of risks for development of the crowd funding mode: First, legal risk. It lies in asymmetric information, the fund investors invested is short of third-party organization's supervision, and it is hard for investors to monitor usages trend of funds before acquiring all the target income of investment projects, so they could not ensure fund security. Therefore, the crowd funding mode is prone to change into illegal fund-raising.

\section{Countermeasures of Internet Financial Risk Supervision}

Internet finance, with characteristics of open, shared, equal, Pratt and Whitney etc., is complement each other with traditional financial industry on aspects of asymmetric information remission, trading efficiency improvement, optimization of resource allocation, rich in investment and financing channels etc.. The sound development of internet finance is benefit to promote the service levels of domestic overall financial industry. On March 5, 2014, Li Keqiang, the prime minister, put forward in the Government Work Report: "promote sound development of internet finance", which laid policy foundations for internet finance. So survey the development and supervision problems of domestic financial industry from view of national strategy is particularly important.

2.1. Focus on and prevent the systematic risks of internet finance. The financial risk due to the out of control of internet finance easily leads to financial market and economic fluctuation, even imperil social stability. Firstly, the entry threshold of internet finance is relatively low, which not only bring larger impact on traditional banking business but disturb orders of the traditional financial market with needs of interests-driven or seize the market. Next, many auditing processes of traditional banks are omitted by the internet finance depending on modern information technology to provide convenient and fast capital turnover, bank deposits and loans etc. services for consumers. However, the reduction of auditing processes might increase possibility of risk accumulation and the short-time financial liquidity would be easily impacted, leading to squeeze disturbance and other problems. Especially under background of internet widely popularized and financial size rapidly expanded, some small probability event might be turned to systematic financial risk quickly. Therefore, contingency plan shall be prepared in advance for the systematic financial risk might be caused by internet finance, and conduct intervention and solution timely.

2.2. Implement dynamic classified supervision. Further identify concepts of financial supervision and divide supervision levels are needed. Supervision can be divided into four levels from loose to strict: market discipline, registration specification, prudential regulation and strict management. Regular assessment shall be conducted according to different internet financial platform, effect degree of products and risk magnitudes; the supervisory scope shall be delimited and supervision strength shall be quantized according to the assessment result; as well as adopt corresponding 
supervision methods according to the final assessment result. For example, control the internet financial service with low risk and effect degree through market discipline and registration modes to strictly supervise the financial service with high risk and effect degree. Meanwhile, the scope of regulation shall be adjusted at any moment according to changes of financial products and services, and the monitoring program on corresponding steps shall be formulated for mechanisms on risk formations of different products.

2.3. Conduct comprehensive monitoring and analysis for the internet finance data. Big data lays a solid foundation for internet finance development and provides methods for supervisors to enhance recognition, monitor, measurement and control of internet financial risks. Acquiring sufficient data information timely is the basis and key for supervisors to completely comprehend the internet financial risk. Therefore, the information monitoring technical standard shall be formulated based on good industrial practices; the data monitoring, analysis index definition, scope of statistics, frequency etc. shall be jointly formulated by the supervisors and practitioners to establish and perfect the data monitoring and analysis mechanism. New risks of internet finance are changeable, so information monitoring shall be remained with sufficient flexibility, monitor effect shall be assessed regularly with continues improvement to avoid supervision loopholes and vacuum. In order to avoid the loophole and "black hole" of internet supervisions, all-around real-time monitoring shall be conducted for the data information to determine the risk conditions based on the overall evaluation of big data.

2.4. Internet financial enterprises and supervision organization shall keep good, smooth and constructive communication channels. For the supervised, the internet financial enterprises should recognize that all-around monitoring for internet finance is actually benefit to firm growth, only then can supervisors and the supervised jointly and actively participate in risk prevention. The internet financial enterprises are main parts of internet market, the self-discipline is particularly important under the environment of existing legal deficiencies. It will not only go against the industry development and economic stability but the enterprise itself might break the law if enterprise blindly operates for pursuing profits. Therefore, internet financial enterprises shall keep good, smooth and constructive communication channels with supervision organizations, clear and definite the law of internet financial operation and actively accept constructive suggestions of supervision organizations. Meanwhile, internet regulator shall give sufficient consideration to operating model of internet financial enterprise and the particularity of risk management and control, help to integrate the supervision requirement into internal control system of the enterprise to reduce running cost and regulatory cost.

2.5. Promote regulatory coordination of different departments. Internet finance spans two industrial forms of finance and internet, the scope it involves is much larger than that of past financial service industry, so effective supervision for the risk prevention and control is particularly important. However, it is not real to supervise the market with conditional constraints of available manpower and material resources. Strengthen internal organization coordination of supervisors is recommended. Build information sharing platform and strengthen standpoint coordination are important contents for each regulation coordination mechanism. Firstly, strengthen coordination among "One Bank and Three Commissions" of the traditional financial regulator. Regulators shall make overall plans and coordination, share internet finance operation and risk etc. information, strengthen cross-functional communication, coordinate supervision position and unify supervision requirement s of industry access and risk fund provision etc. by using idea of "Big Finance" through existing financial regulation coordination mechanism. Next, strengthen the cooperation among the financial regulators and public security organs etc. judicial departments, fight internet finance 
crimes. Finally, strengthen the coordination and cooperation between financial supervision departments with Ministry of Industry and Information Technology, Ministry of Finance, National Development and Reform Commission, local government and other interested parties, maintain financial stability and prevent the regional and systematic financial risks.

2.6. Enhance propaganda and education about consumer's self-protection awareness. Strengthen consumer education is the key to improve acceptability and recognition degree of the public for internet finance. On one hand, it is conducive for the public to understand the internet financial products and increase participation enthusiasm; on the other hand, it is conducive for the public to improve internet financial risk awareness and rationally participated in. Use mass information on internet platform is help to solve problems of traditional financial exaggerated earnings, sale misguidance or insufficient risk warning etc. Internet finance must avoid these problems while making full use of its advantages, comprehensively and accurately disclose the earnings situations, make sufficient and showy risk warnings, earnestly fulfill the consumer education obligation and validly control compliance risks in financial product sales. Guide consumers to rationally participate, recognize innovations of internet financial service than the traditional financial services and the related properties and risk characteristics.

\section{References}

[1] Reuben Abraham. Mobile phones and economic development: evidence from the fishing industry in India. Information Technologies and International Development, 4(1):5一17, 2007.

[2] Agrawal, etal. Challenges and Opportunities with Big Data [R] .Cyber Center Technical Reports, 2012

[3] Yan. Risk Types and Risk Amplification of Online Finance [J].lnformation Technology Journal, 2013,12 (3) :494-497 